\title{
Transport and detoxification of manganese and copper in plants
}

\author{
Tanja Dučić and Andrea Polle*
}

Institut für Forstbotanik, Georg August Universität, 37077 Göttingen, Germany. *Corresponding author: apolle@gwdg.de

\begin{abstract}
Heavy metals like $\mathrm{Mn}$ and $\mathrm{Cu}$, though essential for normal plant growth and development, can be toxic when present in excess in the environment. For normal plant growth maintenance of metal homeostasis is important. Excess uptake of redox active elements causes oxidative destruction. Thus, uptake, transport and distribution within the plant must be strongly controlled. Regulation includes precisely targeted transport from the macro-level of the tissue to the micro-level of the cell and organelles. Membrane transport systems play very important roles in metal trafficking. This review provides a broad overview of the long distance and cellular transport as well as detoxification and homeostasis mechanisms of $\mathrm{Mn}$ and $\mathrm{Cu}$, which are essential micronutrients but extremely toxic at elevated concentrations.
\end{abstract}

Key words: copper, heavy metals, manganese, phytoremediation, transport.

Transporte e destoxificação de manganês e cobre em plantas: Metais pesados como $\mathrm{Mn}$ e $\mathrm{Cu}$, apesar de essenciais para o crescimento e desenvolvimento normal das plantas, podem ser tóxicos quando em excesso no ambiente. Para a manutenção do crescimento normal das plantas, a homeostase de metais é importante. Absorção excessiva de elementos redutores ativos causa destruição oxidativa. Dessa forma, absorção, transporte e distribuição pela planta devem ser controlados. O controle inclui o transporte precisamente direcionado a partir do nível macrotecidual para o nível micro, de células e organelas. O sistema de transporte de membranas parece desempenhar um papel muito importante no trânsito de metais. Esta revisão cobre amplamente o transporte a longa distância e o celular, como também mecanismos de destoxificação e homeostase de $\mathrm{Mn}$ e Cu, os quais são micronutrientes essenciais, mas extremamente tóxicos em elevadas concentrações.

Palavras-chave: cobre, fitorremediação, manganês, metais pesados, transporte.

\section{INTRODUCTION}

In its strict sense the term "heavy metals" includes only elements with densities above $5 \mathrm{~g} \mathrm{~cm}^{-3}$ but frequently biologists use this term for a vast range of metals and metalloids which are toxic to plants such as $\mathrm{Cu}, \mathrm{Fe}, \mathrm{Mn}$, $\mathrm{Zn}, \mathrm{Ni}, \mathrm{As}$, etc. Heavy metals occur regionally in natural soils. Of particular concern is, however, soil pollution with heavy metals introduced by human activities. The United Nations and the International Union of Biological Sciences list threshold values of heavy metals for plants (International Union of Biological Sciences, 1994). Among these pollutants copper is a major contaminant which is released into the environment by anthropogenic activities, e.g. from bactericides, fungicides, and industrial wastes. The regulatory limits for heavy metals in soils are set by national legislation. In the European communities the threshold for copper is $360 \mathrm{~g} \cdot \mathrm{ha}^{-1} \cdot \mathrm{a}^{-1}$, while critical levels for Germany and many European countries are in the range of $20-60 \mathrm{mg} \cdot \mathrm{kg}^{-1}$. In contrast to $\mathrm{Cu}$, figures for soil concentrations of manganese are not meaningful since the plant availability of this element depends strongly on soil $\mathrm{pH}$. The availability of $\mathrm{Mn}$ increases as soil $\mathrm{pH}$ decreases. When the soil $\mathrm{pH}$ drops below $5.5, \mathrm{Mn}$ toxicity may be evident, whereas above $\mathrm{pH} 6.5$ deficiencies are more likely. At lower $\mathrm{pH}$ the manganous $\mathrm{Mn}^{2+}$ predominates and is more readily available to the plant. At higher $\mathrm{pH}$ the manganic form $\mathrm{Mn}^{3,4-7+}$ dominates and is less plant available. Liming acid soils changes the availability of Mn by changing soil solution $\mathrm{pH}$ and the form of manganese. Soil acidification, e.g. by use ammonia-based fertilisers, can result in manganese toxicity. 
Unlike highly toxic contaminants such as cadmium or lead, which have no known function in plants, elements like copper and manganese are essential nutrients necessary for normal growth and development of plants. Both $\mathrm{Cu}$ and $\mathrm{Mn}$ are transition metals involved in cellular redox reactions. The fine control of cellular concentrations of these transition metals needs to be strongly adjusted. Any change away from the threshold level can lead to toxic or deficiency effects. An excess of a transition element can induce a range of negative effects including the production of reactive oxygen species via the Fenton reaction, the exchange of essential metal ions from the active centres of enzymes or binding to functional groups (sulfhydryl, phosphate or histidyl groups) (Elstner et al., 1988), causing visible symptoms like chlorosis, necrosis and growth inhibition (Marschner, 1995). Since transition metals are also essential components in reaction centres of enzymes, deficiency will also lead to stress symptoms.

The biochemical responses of higher plants to toxic doses of heavy metals are very complex and several defence strategies have been suggested. These include complexation of metal ions, reduced influx of metals and enhanced production of antioxidants that detoxify reactive oxidative species produced in response to toxic metals (Van Assche and Clisters, 1990; Radotić et al., 2000; Schützendübel and Polle, 2002). To avoid toxic effects at high concentrations but also deficiency, it is necessary that plants regulate the detoxification of these metals. This can be achieved by controlling uptake and transport, or by sequestration and compartmentalization. The aim of this review is to provide a short overview of uptake, distribution, transport, homeostasis and detoxification of the redox active micronutrients copper and manganese, which are of major concern as environmental contaminants.

\section{Copper: metabolic function and toxicity}

Copper is required for plant nutrition only in trace amounts and at higher concentrations can be toxic to cells. Critical deficiency levels are in the range of $1-5 \mathrm{mg} \cdot \mathrm{kg}^{-1}$ plant dry mass and the threshold for toxicity is above $20-30 \mathrm{mg} \cdot \mathrm{kg}^{-1}$ dry mass (Marschner, 1995). Some hyperaccumulators may accumulate up to $1000 \mathrm{mg} \mathrm{Cu} \cdot \mathrm{kg}^{-1}$ in leaves (Morrison et al., 1981). Copper is a redox-active metal with an electrochemical potential of $-260 \mathrm{mV}$. Thus, it is not surprising that copper is an essential component of many electron carriers involved in reactions occurring in the range from $-420 \mathrm{mV}$ to $+800 \mathrm{mV}$. For example $\mathrm{Cu}$ is present in plastocyanin (photosynthesis), cytochrome $c$ oxidase (respiration), laccases, superoxide dismutase, ascorbate oxidase (antioxidative defence) and is involved in the control of hormone metabolism (ethylene receptor, Rodriguez et al., 1999).

Copper is normally found only in protein-bound forms in cells, since as a free ion it may generate oxidative stress and cause serious damage to organic molecules. This means, the reactivity of copper that makes it so useful in redox reaction also makes it toxic. Free copper ions readily oxidize thiol bonds within proteins, causing a disruption of their secondary structure. The principal mechanism of copper toxicity involves the Fenton reaction, characterised by metal catalysed production of hydroxyl radicals from superoxide and hydrogen peroxide (Elstner et al., 1988; Briat and Lebrun, 1999):

$$
\begin{aligned}
& \mathrm{O}_{2}{ }^{--}+\mathrm{Cu}^{2+} \mathrm{B} \mathrm{O}_{2}+\mathrm{Cu}^{+} \\
& \mathrm{H}_{2} \mathrm{O}_{2}+\mathrm{Cu}^{+} \mathrm{B} \mathrm{Cu}^{2+}+\mathrm{OH}^{-}+\mathrm{OH} \cdot
\end{aligned}
$$

This process has been demonstrated in isolated chloroplasts (Sandmann and Böger, 1980), intact algal cells (Sandmann and Böger, 1980) and in intact roots (De Vos et al., 1993). Reactive oxygen species destruct biological macromolecules like proteins, lipids, DNA, and as a consequence cause cell death by necrosis or apoptosis (programmed cell death, Dat et al., 2000). Although the biochemical response to copper in plants is increasingly well understood, the mechanism of copper tolerance in plants is still unknown. Copper toxicity activates superoxide dismutase and ascorbate peroxidase in sunflower and bean seedlings (Cuypers et al., 1999; García et al., 1999) and in isolated chloroplasts of a microalga (Okamoto et al., 2001). In addition, plants exposed to copper produce phytochelatins, thiol-rich peptides, synthesized from glutathione (GSH), which may chelate copper (Cobbett and Goldsbrough, 2002). Tolerant plants were able to maintain their constitutive functions by decreasing the rate of $\mathrm{Cu}-$ influx, detoxification of the metal through phytochelatin production and quenching of reactive oxygen species (ROS) by superoxide dismutase activity (Hartley-Whitaker et al., 2001). Copper can induce similar stress responses to those evoked by ultraviolet radiation in Lemna gibba, i.e. it increases the levels of ROS and induces the same flavonoides as UV-B, supporting the theory that production of ROS is a common signal to activate defence responses (Babu et al., 2003).

Chuan-Ming and co-workers (2003) found that rice roots underwent rapid cell death upon copper treatment, which could be partially blocked by a MAPK kinase inhibitor. This suggests that the mitogen-activated protein kinase cascade 
may function in the plant copper-induced signalling pathway (Chuan-Ming et al., 2003).

\section{Manganese: metabolic function and toxicity}

Manganese is an essential micronutrient throughout all stages of plant development. It is important for vital plant functions. Mn acts as the cofactor of various enzymes such as Mn-superoxide dismutase, Mn-catalase, pyruvate carboxylase, and phosphoenolpyruvate carboxykinase. Therefore, the incorporation of Mn by cells is essential, particularly in photosynthesis, where Mn plays a critical role as an accumulator of positive charge equivalents in a reaction catalyzed in photosystem II (Marschner, 1995). Mn aids the synthesis of chlorophyll and assimilation of nitrate and activates enzymes of fat biosynthesis. It functions in the formation of riboflavin, ascorbic acid, and carotene.

Plant species differ considerably in their normal or adequate Mn leaf concentrations (30-500 mg Mn. $\mathrm{kg}^{-1}$ dry mass, Clarkson, 1988) and in their susceptibility to Mn deficiency (Reuter et al., 1988; Marschner, 1995; Mengel and Kirkby, 2001). The critical deficiency range in fully expanded leaves is reached when Mn concentrations drop below 10 to $20 \mathrm{mg}$ Mn. $\mathrm{kg}^{-1}$ dry mass (Marschner 1995). $\mathrm{Mn}^{2+}$ toxicity can be an important factor limiting plant growth, particularly in acidic, poorly-drained soils (Horst, 1988). On the other hand, the critical concentration for toxicity can vary within a very wide range, depending on plant species and genotypes within species, and on environmental conditions, such as temperature and $\mathrm{Si}, \mathrm{Ca}, \mathrm{Mg}$, or Fe nutritional status (Horst, 1988; Le Bot et al., 1990; Wang et al., 1992). Critical toxicity concentrations ranging from $200 \mathrm{mg} \cdot \mathrm{kg}^{-1}$ to $5300 \mathrm{mg} \cdot \mathrm{kg}^{-1}$ dry mass have been reported by Edwards and Asher (1982). Since Mn is involved in oxygen radical detoxification via Mn-SOD, in Mn-deficient plants cell metabolism cannot efficiently control excess formation of oxygen radicals and oxidative damage occurs (Tanaka et al., 1995; Yu et al., 1998; Yu and Rengel, 1999). Intimate interactions of Mn-nutrition and antioxidant metabolism exist since cytosolic CuZn-SOD and mitochondrial Mn-SOD activities increase under conditions of Mn-excess as well as Mn-starvation (Shenker et al., 2004).

Manganese has several different chemical roles in biological systems. It is involved in scavenging of superoxide and hydrogen peroxide:

$$
\begin{aligned}
& \mathrm{Mn}(\mathrm{II})+\mathrm{O}_{2}^{--}+2 \mathrm{H}^{+} \mathrm{B} \mathrm{Mn}(\mathrm{III})+\mathrm{H}_{2} \mathrm{O}_{2} \\
& \mathrm{Mn}(\mathrm{III})+\mathrm{H}_{2} \mathrm{O}_{2} \text { B ÊMn(II) }+\mathrm{O}_{2}+2 \mathrm{H}^{+}
\end{aligned}
$$

The exact mechanism for catalytic scavenging of $\mathrm{H}_{2} \mathrm{O}_{2}$ is, however, not clear and thought to involve intermediate steps.
Reaction intermediates, $\mathrm{O}_{2}{ }^{--}$and $\mathrm{OH}^{\bullet}$ have been observed in vitro (Stadtman et al., 1990).

Excess $\mathrm{Mn}$ results in apoplastic deposition of oxidized $\mathrm{Mn}$ and phenolics. There is evidence that peroxidases are involved in this reaction (Fecht-Christoffers et al., 2003). Mn also induces PR- and thaumatin-like proteins in the apoplast. However, it is still unclear whether these responses belong to the activation of protection against $\mathrm{Mn}$ or whether these typical defence reactions occur relatively non-specifically due to $\mathrm{Mn}$-induced $\mathrm{H}_{2} \mathrm{O}_{2}$-production and injury (Horst et al., 1999).

\section{Intracellular detoxification}

When metal ions are taken up into the cells, properties like high reactivity or limited solubility require their chelation. This was demonstrated for copper in yeast, which contains less than one "free" copper atom (Rae et al., 1999). The metal ions are bound by chelators and chaperons. Chelators contribute to metal detoxification by buffering cytosolic metal concentrations, while chaperones specifically deliver metal ions to organelles and metal-requiring proteins (Clemens, 2001). In plants, the metal chelators include phytochelatins, metallothioneins, organic acid, and amino acids.

Phytochelatins (PCs) are a group of metal-binding peptides with the general structure $(\gamma \text {-glu-cys })_{n}$ gly $(n=2-$ 11) (Grill et al., 1985; Cobbett, 2000). PCs are synthesized non-translationally from GSH by PC synthase (Grill et al., 1989). PCs are induced by a range of metals and metalloids like Cd, Zn, Cu, As (Grill et al., 1985; De Vos et al., 1992). Glutathione has a dual role in response to metal stress, as an antioxidant and precursor for chelators. It has been suggested that PC production resulting in GSH depletion may itself cause oxidative stress (Schützendübel et al., 2001; De Vos et al., 1992). PC synthesis is activated within minutes following exposure to a variety of metals and metalloids. $\mathrm{Cu}, \mathrm{Ag}$ and As are detected in complexes with PCs (Maitani et al., 1996; Schmöger et al., 2000). The Arabidopsis cad1-3 mutant, which lacks expression of PC-synthase, is highly sensitive to $\mathrm{Cd}^{2+}$ and $\mathrm{AsO}_{4}{ }^{2-}$ compared to wild type plants and also displays elevated sensitivities towards $\mathrm{Cu}, \mathrm{Hg}$ and $\mathrm{Ag}$ ( $\mathrm{Ha}$ et al., 1999). Overexpression of AtPCS1, a gene encoding PCsynthase in $\mathrm{S}$. cerevisiae increased $\mathrm{Cd}, \mathrm{Hg}$ and As tolerance, whereas the effect on $\mathrm{Cu}$ sensitivity was small (Vatamaniuk et al., 1999). These data show the importance of PCs for the detoxification of a range of metals and metalloids, but also demonstrate that they cannot be the only mechanism of metal tolerance in plants. 
Metallothioneins (MTs) are cysteine-rich low molecular weight proteins, which can bind metal ions in metal-thiolate clusters (Hamer, 1986). MTs are ubiquitous among all organisms and are grouped into several classes depending on the arrangement of Cys residues: class-I MTs from mammalian cells are known to confer Cd tolerance (Fowler et al., 1987) and play important role in Zn homeostasis. Yeast MTs, which belong to class II, appear to bind mainly $\mathrm{Cu}$. Disruption of cup 1 caused $\mathrm{Cu}$ hypersensitivity and overexpression led to $\mathrm{Cu}$ tolerance (Yu et al., 1994). In plants more than 50 MTlike sequences have been found in different species (Rauser, 1999). In trees, MTs belong to the most highly expressed gene products (unpublished data). With few exceptions $\left(\mathrm{E}_{\mathrm{c}}\right.$ from wheat and MT1 and MT2 from Arabidopsis, Lane et al., 1987; Zhou and Goldsbrough, 1994; Murphy et al., 1997), the roles of MTs are not well understood. Wheat $\mathrm{E}_{\mathrm{c}}$ was shown to form associations with metals (Lane et al., 1987; Kawashima et al., 1992). Functional data have been obtained from heterologous systems, e.g. the copper-sensitivity of the S. cerevisiae cup $1 \Delta$ strain can be suppressed by expression of Arabidopsis MT1 and MT2 (Zhou and Goldsbrough, 1994). These data suggest a role of MT-like genes and their products in plant metal homeostasis. Proposed functions include detoxification of copper, cytosolic zinc buffering, scavenging of metals during leaf senescence, or involvement in metal secretion via leaf trichomes (Robinson et al., 1996; Garcia-Hernandez et al., 1998; Rauser, 1999).

Carboxyl and amino groups also present potential ligands for metal ions. Citrate, malate and oxalate have been included in different metal tolerance processes, like transport through the xylem and vacuolar sequestering (Rauser, 1999). For example citric acid has been hypothesized to be a major $\mathrm{Cd}$ ligand at low concentration of Cd (Wagner, 1994) and can form complexes with $\mathrm{Ni}$ in Ni-hyperaccumulator plants (Sagner et al., 1998). Malate is a very good cytosolic Znchelator in Zn-tolerant plants (Mathys, 1977).

Free proline accumulation has been observed in response to a wide range of abiotic and biotic stresses in plants. It is considered to be one of the first metabolic responses to stress, possibly in many cases acting as an osmolyte (Hare and Cress, 1997). Cu tolerance was positively correlated with free proline content in lichen chlorophyta (Bačkor et al., 2003). Formation of $\mathrm{Cu}$-complexes with amino acids including proline has been studied frequently and it seems that copper complexes with proline, histidine or nicotinamine play important roles in xylem sap transport (Liao et al., 2000).

\section{Intracellular transport, distribution and homeostasis}

One important task of cell metabolism is to supply proteins with the correct metal cofactors needed for their activity and moreover to deliver these cofactors at the right time and to the right site of the target protein. At the same time possible toxic reactions of the metals need to be avoided. It is, therefore, crucial that among the many different metals accumulated by cells, only the correct ion is presented to the metalloproteins (Luk et al., 2003a). Thus, when metals enter a cell, they are delivered to one of several possible pathways, depending on physiological needs. These routes are usually are called "metal trafficking pathways".

After $\mathrm{Cu}$-uptake into the cell, homeostasis is maintained by copper chaperones involved in intracellular transport (Company and González-Bosch, 2004). These chaperons sequester copper in a non-reactive form and interact with other transport proteins to deliver copper to the sites where it is needed (Himelblau and Amasino, 2000). Two genes have been identified in Arabidopsis thaliana (copper chaperone and response to antagonist1 (RAN1)) with high homologies to copper-trafficking genes from yeast and humans involved in sequestering free copper ions in the cytoplasm and delivering it to post-Golgi vesicles (Himelblau and Amasino, 2000). Mutant analysis further showed that RAN1 was involved in ethylene reception because suppression of RAN1 blocked ethylene responses. It was suggested that this plant copper-delivery pathway is required to create functional ethylene receptors (Himelblau and Amasino, 2000). Further details of copper intracellular transport and homeostasis can be found in the review of Polle and Schützendübel (2003).

Members of the ZIP gene family, a novel metal transporter family first identified in plants, are capable of transporting a variety of cations, including cadmium, iron, manganese and zinc. Information on where in the plant each of the ZIP transporters functions and how each is controlled in response to nutrient availability, may allow the manipulation of plant mineral status developing plants that bioaccumulate or exclude toxic metals (Guerinot, 2000).

The molecular basis for the transport of manganese across membranes in plant cells is poorly understood. IRT1, a member of the ZIP family, identified in A. thaliana is a broad-range metal ion transporter. It can complement a mutant Saccharomyces cerevisiae strain defective in highaffinity manganese uptake (smfl $\Delta$ ) (Korshunova et al., 1999). The IRT1 protein has previously been identified as an iron transporter, but later it was demonstrated that IRT1, when expressed in yeast, can transport manganese as well. 
This manganese uptake activity was inhibited by cadmium, iron(II) and zinc, suggesting that IRT1 can transport these metals. However, IRT1 did not complement a copper uptakedeficient yeast mutant (ctr1), implying that this transporter is not involved in the uptake of copper into plant cells (Korshunova et al., 1999) (figure 1).

Recently, Lopez-Millan and colleagues (2004) identified new metal transporters in the legume Medicago truncatula with high similarities to the ZIP family (MtZIP). Six proteins, predicted from cDNA sequences, all contained eight transmembrane domains and the highly conserved ZIP signature motif which functions as metal transporter. When MtZIPs were transformed into appropriate metal-uptake defective yeast mutants and grown on metal-limited media, MtZIP4 and MtZIP7 proteins restored yeast growth on Mnlimited media, whereas another complemented growth on $\mathrm{Zn}$ and Fe-limited media. In Mn-deficient plants, the transcript levels of MtZIP3 and MtZIP4 were down-regulated. MtZIP5 expression was up-regulated under Mn-limiting conditions in leaves, but in roots it appeared to be down-regulated under Mndeficient and toxicity conditions. The expression of MtZIP6 and MtZIP7 was unaffected by the metal supply. Future work will reveal the role of these proteins in the regulation/execution of plant metal homeostasis (Lopez-Millan et al., 2004).
One of the transporters for manganese in cells is SMF1, a member of the Nramp family comprised of divalent metal transporters (Cellier et al., 1995). Since SMF1 seems to be a high affinity transporter activated under manganese starvation, under normal physiological conditions other highaffinity transporter(s) must be operating (Luk et al., 2003a,b). S. cerevisiae PHO84 is a well-known transporter for the high-affinity uptake of phosphate; recently, a role for this protein in manganese transport has been uncovered (Luk et al., 2003a,b). Yeast cells lacking PHO84 exhibited resistance to manganese toxicity accumulating only low Mn-levels. It is quite possible that phosphate transporters also contribute to manganese uptake in other organisms, particularly under conditions of manganese toxicity. Luk and co-workers (2003a,b) hypothesized that in yeast PHO84 can transport phosphate in the form of $\mathrm{MnHPO}_{4}$ (figure 1). Our own data show a tight correlation between phosphor and manganese in "black bodies" which are formed in roots of Douglas fir under Mn-stress (Dučić and Polle, unpublished data).

One way to prevent the toxic effect of heavy metals is efflux. To facilitate manganese efflux from the cell, the metal is delivered into the Golgi apparatus and ultimately exported from the cell via secretory pathway vesicles that carry the metal to the cell surface (cf. figure 1). P-type ATPase, known

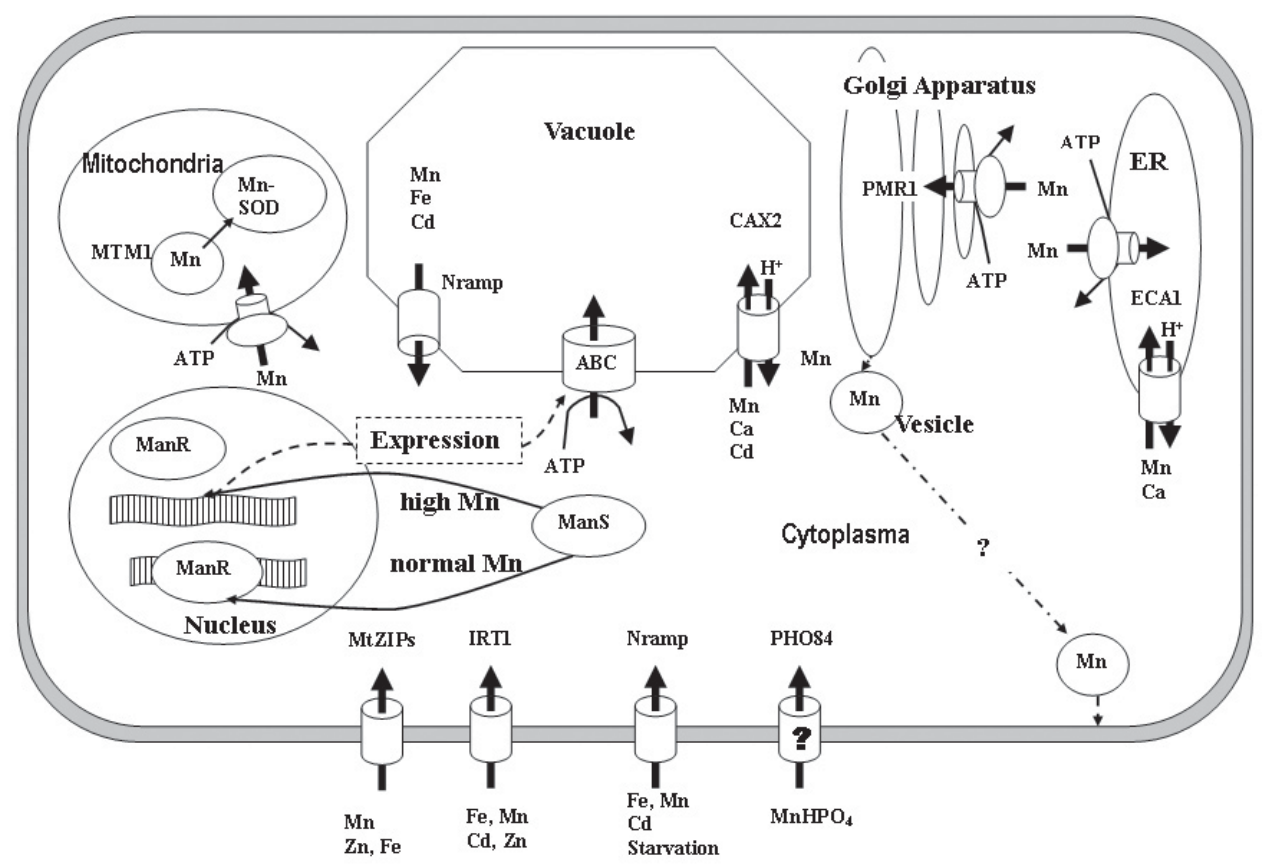

Figure 1. Hypothetic view of Mn-trafficking and cellular sensing. IRT1, Nramp and PHO84 are transporters putatively mediating Mn-uptake. Inside the cell, ATPases pump Mn into subcellular compartments (ER = endoplasmatic reticulum, Golgi apparatus, and plastids). Vacuolar Mn-transport is achieved by CAX2, an $\mathrm{H}^{+} / \mathrm{Me}^{2+}$-antiporter. In mitochondria, MTM1 functions as a Mn-chaperone delivering Mn specifically to Mn-superoxide dismutases. MnS, a His-Kinase, acts as a Mn sensor and suppresses activation of ABC transporter expression under normal conditions by repressing MnR. For further details, see text. 
as PMR1 (transporters for both calcium and manganese) pump manganese into the secretory pathway (Rudolph et al., 1989; Durr et al., 1998). Yeast cells lacking the PMR1 transporter are extremely sensitive to manganese and accumulate high concentrations of the metal, presumably in the cytosol (Lapinskas et al., 1995).

Another way to prevent metal toxicity is compartmentalization. Several transporters can potentially mediate transport of metals and compartmentalization. These include the heavy metal ATPases (HMAs), the Nramps, the cation diffusion facilitator (CDF) family, the ZIP family, and the cation antiporters (Hall and Williams, 2003). For example, among multiple $\mathrm{Ca}^{2+}$ pumps and $\mathrm{Ca}^{2+} / \mathrm{H}^{+}$antiporters in Arabidopsis, ECA1, which pumps $\mathrm{Ca}^{2+}$ and $\mathrm{Mn}^{2+}$ into the endoplasmic reticulum, is required to support plant growth under conditions of $\mathrm{Ca}^{2+}$ deficiency or $\mathrm{Mn}^{2+}$ toxicity (Zhongyi et al., 2002) (figure 1).

The main storage compartment for toxic compounds in plants is the vacuole (Vögeli-Lange and Wagner, 1990). Mutants of vacuolar ATPases exhibited manganese sensitivity (Ramsay and Gadd, 1997). In plants and fungi, vacuolar transporters help to remove potentially toxic cations from the cytosol. Metal $/ \mathrm{H}^{+}$antiporters are involved in metal sequestration into the vacuole. The $A$. thaliana cation exchangers, CAX1 and CAX2, can both transport $\mathrm{Ca}^{2+}$ into the vacuole. There are $11 \mathrm{CAX}$-like transporters in Arabidopsis; however, CAX2 is the only characterized CAX-transporter capable of vacuolar $\mathrm{Mn}^{2+}$ transport when expressed in yeast (Shigaki et al., 2003) (figure 1). The subdomain analysis identified 3 amino acid regions responsible for $\mathrm{Mn}^{2+}$ specificity in CAX2 (Shigaki et al., 2003). Tobacco plants overexpressing CAX2 accumulated more $\mathrm{Ca}^{2+}, \mathrm{Cd}^{2+}$, and $\mathrm{Mn}^{2+}$ than wild type plants and were more tolerant to elevated $\mathrm{Mn}^{2+}$ levels. Expression of CAX2 in tobacco increased $\mathrm{Cd}^{2+}$ and $\mathrm{Mn}^{2+}$ transport in isolated root tonoplast vesicles (Hirschi et al., 2000).

The ABC-transporter superfamily is one of the largest transporter families, and members can be found in bacteria, fungi, plants and animals. The first reports on plant $\mathrm{ABC}$ transporters showed that they are implicated in detoxification processes (Martinoia et al., 2002). The recent completion of the genomic sequencing of $A$. thaliana showed that Arabidopsis contains more than 100 ABC-type proteins; 53 genes code for so-called full-size transporters. Work on the cyanobacterium Synechocystis sp. PCC 6803 suggests possible roles for $\mathrm{ABC}$ transporters in $\mathrm{Mn}^{2+}$ transport (Bartsevich and Pakrasi, 1995). Photosynthesis activity and growth rates were restored in photosynthesis-deficient mutants by the addition of Mn (Bartsevich and Pakrasi, 1995, 1996). Yamaguchi and co-workers (2002) using a DNA microarray, screened knockout libraries of His kinases and response regulators of Synechocystis sp. PCC 6803 to identify possible participants in the mechanisms for maintaining cytoplasmic $\mathrm{Mn}^{2+}$ ion homeostasis. They identified a His-kinase, ManS, which might sense the extracellular concentration of $\mathrm{Mn}^{2+}$ ions, and a response regulator, ManR, which might regulate the expression of the mntCAB operon for the ABC-type transporter of $\mathrm{Mn}^{2+}$ ions (Yamaguchi et al., 2002). It was suggested that ManS produces a signal that activates ManR, which represses the expression of the $m n t C A B$ operon during normal Mn concentration in cell (Yamaguchi et al., 2002) (figure 1).

The intracellular trafficking of manganese in yeast was also highly dependent on SMF2, another member of the Nramp family (West et al., 1992). Yeast cells devoid of the SMF2 transporter exhibited deficiencies in invertase glycosylation and manganese SOD2 activity indicating cell-wide disturbance caused by inappropriate manganese trafficking (Luk and Cullota, 2001). One protein, a member of the mitochondrial carrier family (MCF) appeared to be specifically involved in the delivery of Mn to Mn-SOD2 and, thus was termed MTM1 (manganese trafficking factor for mitochondrial SOD2) (Luk et al., 2003b). MTM1 does not globally supply the mitochondria with manganese and does not behave like a classical membrane transporter for manganese, but rather delivers manganese specifically to SOD2. It was concluded that MTM1 is a Mn-chaperone (Luk et al., 2003a) (figure 1).

\section{Long distance transport}

In higher plants the analysis of transport and sequestration of transition metals is complex because of tissue- and cell-specific differences and organ-specific transport. The processes that are assumed to be influencing metal accumulation rates in plants are mobilization and uptake from the soil, compartmentalization and sequestration within the root, efficiency of xylem loading and transport, distribution between metal sinks in the aerial parts, sequestration and storage in leaf cells (Clemens et al., 2002). At each level of the transport within the plant, concentrations and affinities of metal chelators as well as the presence and selectivity of transporters may influence metal accumulation rates.

The apoplast continuum in the root epidermis and cortex is readily permeable for solutes. In general, solutes have to be taken up into the root symplast to cross the endodermis before 
they can enter the xylem (Tester and Leigh, 2001). Following metal uptake into the root symplasm, three processes determine the movement of metals from the root into the xylem: sequestration of metals inside root cells, symplastic transport into the stele and release into the xylem (Clemens et al., 2002). The transport of ions into the xylem is generally a tightly controlled process mediated by membrane transport proteins (Gaymard et al., 1998). Xylem-unloading processes are the first step in controlled distribution and detoxification of metals in the shoot (Schmidke and Stephan, 1995). Copper can also be translocated in the phloem (Schmidke and Stephan, 1995), whereas manganese is thought to be phloem-immobile (Loneragan, 1988).

Generally, however, copper is translocated to a very low extent to the shoot, probably because it strongly accumulates in the cell walls of the cortex, where its concentration sharply decreases from the outer to the inner cell layers (Arduini et al., 1996). Liao et al. (2000) found that transport of $\mathrm{Cu}$ from the roots to the shoot was slowed down by binding of $\mathrm{Cu}$ to roots and lack of $\mathrm{Cu}$ transport capacity in xylem. Theoretical estimations of total $\mathrm{Cu}$ uptake by shoots based on wholeplant water use and xylem $\mathrm{Cu}$ concentrations were much higher than actually measured $\mathrm{Cu}$ accumulation in shoots. This suggests that counter flow of $\mathrm{Cu}$ in the phloem back to roots may be a significant influence on $\mathrm{Cu}$ allocation between shoots and roots (Liao et al., 2000).

The traditional idea is that manganese as a divalent ion can move freely in the xylem sap and is transported to leaves with the transpiration stream. Re-distribution is thought to be limited since $\mathrm{Mn}$ is classified as phloem immobile (Loneragan, 1988). However, even during xylem transport Mn may not be present as a "free" ion but -as mentioned above- may form complexes with organic acids or phosphate (Rauser, 1999; Luk et al., 2003a). Furthermore, the phloem sap also contains high concentrations of Mn (Rengel, 1988). In conifers the sieve cells may participate in Mndeposition and transport since they contained higher Mnconcentrations than the xylem (Dučić and Polle, unpublished results). Radioactive labelling showed that Mn taken up into leaves could be transported back to roots (Dučić and Polle, unpublished data).

\section{Significance of transport and detoxification for phytore- mediation}

Phytoremediation of sites contaminated with metals is particularly challenging. It is one emerging cleanup technology using plants for environmental restoration of metal-con- taminated soil (Baker et al., 1991; Salt et al., 1998; Lasat, 2002). The success of phytoextraction, as an environmental cleanup technology, depends on several factors including the extent of soil contamination, metal availability for uptake into roots (bioavailability), and plant ability to intercept, absorb, accumulate and tolerate metals in the shoot (Ernst, 1996). The bioavailability is strongly modulated by microorganisms catalysing redox reactions leading to changes in metal mobility in the soil and propensity for uptake into roots (Gaur and Adholeya, 2004). In addition, mycorrhizal roots have been shown to affect the rate of metal uptake (Schützendübel and Polle, 2002; Vassilev et al., 2004). The characterisation of key transporters involved in heavy metal uptake and biochemical characterization of tolerance mechanisms are necessary steps to understand the regulation of metal uptake. The identification and isolation of genes involved in the homeostasis of micronutrients may open the opportunity to use biotechnology to ameliorate plants for environmental cleanup. Trees and crops like willow, corn and sunflower show high tolerance to heavy metals. Furthermore, plants exude organic acids and other compounds which may directly chelate metals or serve as nutrients for micoorganisms, thus, indirectly affecting soil properties and metal mobility. Given the toxicity of heavy metals, this kind of technology evokes huge economical and public interest. Nevertheless, it is necessary to conduct more fundamental research to better understand the metabolic pathways and possibilities of the plants to handle metals before efficient strategies can be derived to engineer plants for phytoremediation purposes.

Acknowledgements: We thank the German Science Foundation (DFG) for continuous financial support and the technical staff, especially T. Riemekasten and C. Kettner, for skilful and dedicated assistance.

\section{REFERENCES}

Arduini I, Godbold DL, Onnis A (1996) Cadmium and copper uptake and distribution in Mediterranean tree seedlings. Physiol. Plant. 97:111-117.

Babu TS, Akhtar TA, Lampi MA, Tripuranthakam S, Dixon DG, Greenberg BM (2003) Similar stress responses are elicited by copper and ultraviolet radiation in the aquatic plant Lemna gibba: implication of reactive oxygen species as common signals. Plant Cell Physiol. 44:1320-1329.

Bačkor M, Fahselt D, Davidson RD, Wu CT (2003) Effects of copper on wild and tolerant strains of the lichen photobiont Trebouxia erici (Chlorophyta) and possible tolerance mechanisms. Arch. Environ. Contam. Toxicol. 45:159-167.

Baker AJM, Reeves RD, McGrath SP (1991) In situ decontamination of heavy metal polluted soils using crops of metal- 
accumulating plants - a feasibility study. In: Hinchee RL, Olfenbuttel RF (eds), In situ Bioreclamation, pp.600-605. Butterworth-Heinemann, Boston, USA.

Bartsevich VV, Pakrasi HB (1995) Molecular identification of an $\mathrm{ABC}$ transporter complex for manganese: analysis of a cyanobacterial mutant strain impaired in the photosynthetic oxygen evolution process. EMBO J. 14:1845-1853.

Bartsevich VV, Pakrasi HB (1996) Manganese transport in the cyanobacterium Synechocystis sp. PCC 6803. J. Biol. Chem. 271:26057-26061.

Briat JF, Lebrun M (1999) Plant responses to metal toxicity. Comp. R. Acad. Sci. Paris 322:43-54.

Cellier M, Prive G, Belouchi A, Kwan T, Rodrigues V, Chia W, Gros P (1995) Nramp defines a family of membrane proteins. Proc. Natl. Acad. Sci. USA 91:10089-10093.

Chuan-Ming Y, Wan-Chi H, Hao-Jen H (2003) Copper treatment activates mitogen-activated protein kinase signalling in rice. Physiol. Plant. 119:392-399.

Clarkson DT (1988) The uptake and translocation of manganese by plant roots. In: Graham RD, Hannam RJ, Uren NC (eds), Manganese in soils and plants, pp. 101-111. Kluwer Academic Publishers, Dordrecht, The Netherlands.

Clemens S (2001) Molecular mechanisms of plant metal tolerance and homeostasis. Planta 212:475-486.

Clemens S, Bloss T, Vess C, Neumann D, Nies DH, zur Nieden U (2002) A transporter in the endoplasmic reticulum of Schizosaccharomyces pombe cells mediates zinc storage and differentially affects transition metal tolerance. J. Biol. Chem. 277:18215-18221.

Cobbett CS (2000) Phytochelatins and their roles in heavy metal detoxification. Plant Physiol. 123:825-832.

Cobbett C, Goldsbrough P (2002) Phytochelatins and metallothioneins: roles in heavy metal detoxification and homeostasis. Annu. Rev. Plant Biol. 53:159-182.

Company P, Gonzalez-Bosch C (2003) Identification of a copper chaperone from tomato fruits infected with Botrytis cinerea by differential display. Biochem. Biophys. Res. Commu. 304:825-830.

Cuypers A, Vangronseld J, Clijsters H (1999) The chemical behavior of heavy metals plays a prominent role in the induction of oxidative stress. Free Rad. Res. 31:39-43.

Dat J, Vandenabeele S, Vranová E, Van Montagu M, Inzé D, Van Breusegem F (2000) Dual action of AOS during plant stress responses. Cell. Mol. Life Sci. 57:779-795.

De Vos CHR, Ten Bookum WM, Vooijs R, Schat H, De Kok LJ (1993) Effect of copper on fatty acid composition and peroxidation of lipids in the roots of copper tolerant and sensitive Silene cucubalus. Plant Physiol. Biochem. 31:151-158.

De Vos RCH, Vonk MJ, Vooijs R, Schat H (1992) Glutathione depletion due to copper induced phytochelatin synthesis causes oxidative stress in Silene cucubalus. Plant Physiol. 98:853-858.

Durr G, Strayle J, Plemper R, Elbs S, Klee SK, Catty P, Wolf DH, Rudolph HK (1998) The medial-Golgi ion pump Pmr1 supplies the yeast secretory pathway with $\mathrm{Ca}^{2+}$ and $\mathrm{Mn}^{2+}$ required for glycosylation, sorting, and endoplasmic reticulum-associated protein degradation. Mol. Biol. Cell 9: 1149-1162.

Edwards DG, Asher CJ (1982) Tolerance of crop and pasture species to manganese toxicity. In: Scaife A (ed), Pro- ceedings of the Ninth Plant Nutrition Colloquium, pp.145150. Commonwealth Agricultural Bureaux, Slough, Warwick, England.

Elstner EF, Wagner GA, Schütz W (1988) Activated oxygen in green plants in relation to stress situation. Curr. Top. Plant Biochem. Physiol. 7:159-187.

Ernst WHO (1996) Bioavailability of heavy metals and decontamination of soil by plants. Appl. Geochem. 11:163-167.

Fecht-Christoffers MM, Maier P, Horst WJ (2003) Apoplastic peroxidases and ascorbate are involved in manganese toxicity and tolerance of Vigna unguiculata. Physol. Plant. 117:237-244.

Fowler BA, Hildebrand CE, Kojima Y, Webb M (1987) Nomenclature of metallothionein. Experientia Supplementum 52:19-22.

García A, Baquedano FJ, Navarro P, Castillo FJ (1999) Oxidative stress induced by copper in sunflower plants. Free Rad. Res. 31:45-50.

Garcia-Hernandez M, Murphy A, Taiz L (1998) Metallothioneins 1 and 2 have distinct but overlapping expression patterns in Arabidopsis. Plant Physiol. 118:387-397.

Gaur A, Adholeya A (2004) Prospects of arbuscular mycorrhizal fungi in phytoremediation of heavy metal contaminated soils. Curr. Sci. 86:528-534.

Gaymard F, Pilot G, Lacombe B, Bouchez D, Bruneau D, Boucherez J, Michaux-Ferriere N, Thibaud JB, Sentenac H (1998) Identification and disruption of a plant shakerlike outward channel involved in $\mathrm{K}+$ release into the $\mathrm{xy}-$ lem sap. Cell 94:647-655.

Grill E, Loffler S, Winnacker E-L, Zenk MH (1989) Phytochelatins, the heavy-metal-binding peptides of plants, are synthesized from glutathione by a specific $\gamma$-glutamylcysteine dipeptidyl transpeptidase (phytochelatin synthase). Proc. Natl. Acad. Sci. USA 86:6838-6842.

Grill E, Winnacker E-L, Zenk MH (1985) Phytochelatins: the principal heavy-metal complexing peptides of higher plants. Science 230:674-676.

Guerinot ML (2000) The ZIP family of metal transporters. Biochim. Biophys. Acta 1465:190-198.

Ha S-B, Smith A, Howden R, Dietrich W, Bugg S, O’Connell M, Goldsbrough P, Cobbett C (1999) Phytochelatin synthase genes from Arabidopsis and the yeast Schizosaccharomyces pombe. Plant Cell 11:1153-1163.

Hall JL, Williams LE (2003) Transition metal transporters in plants. J. Exp. Bot. 54:2601-2613.

Hamer DH (1986) Metallothionein Ann. Rev. Biochem. 55: 913-951.

Hare PD, Cress WA(1997) Metabolic implications of stress-induced proline accumulation in plants. Plant Growth Regul. 21:79-102.

Hartley-Whitaker J, Ainsworth G, Meharg A (2001) Copper and arsenic induced oxidative stress in Holcus lanatus L. clones with differential sensitivity. Plant Cell Environ. 24:713-722.

Himelblau E, Amasino RM (2000). Delivering copper within plant cells. Curr. Opin. Plant Biol. 3:205-210.

Hirschi KD, Korenkov VD, Wilganowski NL, Wagner GJ (2000) Expression of Arabidopsis CAX2 in tobacco. Altered metal accumulation and increased manganese tolerance. Plant Physiol. 124:125-133. 
Horsburgh MJ, Wharton SJ, Cox AG, Ingham E, Peacock S, Foster SJ (2002) MntR modulates expression of the PerR regulon and superoxide resistance in Staphylococcus aureus through control of manganese uptake. Mol. Microbiol. 44:1269-1286.

Horst WJ (1988) The physiology of manganese toxicity. In: Graham RD, Hannam RJ, Uren NC (eds), Manganese in soils and plants, pp.175-188. Kluwer Academic Publishers, Dordrecht, The Nederlands.

Horst WJ, Fecht M, Naumann A, Wissemeier AH, Maier P (1999) Physiology of manganese toxicity and tolerance in Vigna unguiculata (L.) Walp. J. Plant Nutr. Soil Sci. 162: 263-274.

International Union of Biological Sciences, 1994. Element concentration cadasters in ecosystems. Progress report, 25th General Assembly, Paris.

Kawashima I, Kennedy TD, Chino M, Lane BG (1992) Wheat Ec metallothionein genes. Like mammalian $\mathrm{Zn} 2+$ metallothionein genes, wheat $\mathrm{Zn} 2+$ metallothionein genes are conspicuously expressed during embryogenesis. Eur. J. Biochem. 209:971-976.

Korshunova YO, Eide D, Clark WG, Guerinot ML, Pakrasi HB (1999) The IRT1 protein from Arabidopsis thaliana is a metal transporter with a broad substrate range. Plant Mol. Biol. 40:37-44.

Krämer U, Cotter-Howells JD, Charnock JM, Baker AJM, Smith JAC (1996) Free histidine as a metal chelator in plants that accumulate nickel. Nature 379:635-638.

Kuhn NJ, Talbot J, Ward S (1991) pH-sensitive control of arginase by $\mathrm{Mn}$ (II) ions at submicromolar concentrations. Arch. Biochem. Biophys. 286:217-221.

Lane BR, Kajoika R, Kennedy R (1987) The wheat germ Ec protein is zinc-containing metallothionein. Biochem. Cell Biol. 65:1001-1005.

Lapinskas PJ, Cunningham KW, Liu XF, Fink GR, Culotta VC (1995) Mutations in PMR1 suppress oxidative damage in yeast cells lacking superoxide dismutase. Mol. Cell. Biol. 15:1382-1388.

Lasat MM (2002) Phytoextraction of toxic metals: a review of biological mechanisms. J. Environ. Qual. 31:109-120.

Le Bot J, Goss MJ, Carvalho GPR, Van Beusichem ML, Kirby EA (1990) The significance of the magnesium to manganese ratio in plant tissues for growth and alleviation of manganese toxicity in tomato (Lycopersicon esculentum) and wheat (Triticum sativum) plants. Plant Soil 124:205-210.

Liao MT, Hedley MJ, Woolley DJ, Brooks RR, Nichols MA (2000) Copper uptake and translocation in chicory (Cichorium intybus L. cv. Grasslands Puna) and tomato (Lycopersicon esculentum Mill. cv. Rondy) plants grown in NFT system. I. Copper uptake and distribution in plants. Plant Soil 221:135-142.

Loneragan JF (1988) Distribution and movement of manganese in plants. In: Graham RD, Hannam RJ, Uren NC (eds), Manganese in soils and plants, pp.113-124. Kluwer Academic Publishers, Dordrecht, The Nederlands.

Lopez-Millan AF, Ellis DR, Grusak MA (2004) Identification and characterization of several new members of the ZIP family of metal ion transporters in Medicago truncatula. Plant Mol. Biol. 54:583-596.
Luk E, Carroll M, Baker M, Cizewski Culotta V (2003a) Manganese activation of superoxide dismutase 2 in Saccharomyces cerevisiae requires MTM1, a member of the mitochondrial carrier family. Proc. Natl. Acad. Sci. USA 100:10353-10357.

Luk E, Culotta VC (2001) Manganese superoxide dismutase in S. cerevisiae acquires its metal co-factor through a pathway involving the Nramp metal transproter, Smf2p. J. Biol. Chem. 276:47556-47562.

Luk E, Jensen LT, Culotta VC (2003b) The many highways for intracellular trafficking of metals. J. Biol. Inorg. Chem. Soc. 8:803-809.

Maathuis FJ, Filatov V, Herzyk P, Krijger GC, Axelsen KB, Chen S, Green BJ, Li Y, Madagan KL, Sanchez-Fernandez R, Forde BG, Palmgren MG, Rea PA, Williams LE, Sanders D, Amtmann A (2003) Transcriptome analysis of root transporters reveals participation of multiple gene families in the response to cation stress. Plant J. 35:675-692.

Maitani T, Kubota H, Sato K, Yamada T (1996) The Composition of Metals Bound to Class III Metallothionein (Phytochelatin and Its Desglycyl Peptide) Induced by Various Metals in Root Cultures of Rubia tinctorum. Plant Physiol. 110:1145-1150.

Marschner H (1995) Mineral Nutrition of Higher Plants. Academic Press, London.

Martinoia E, Klein M, Geisler M, Bovet L, Forestier C, Kolukisaoglu U, Muller-Rober B, Schulz B (2002) Multifunctionality of plant $\mathrm{ABC}$ transporters - more than just detoxifiers. Planta 214:345-355.

Mathys W (1977) The role of malate, oxalate and mustard oil glucosides in the evolution of zinc-resistance in herbage plants. Physiol. Plant. 40:130-136.

Mengel K, Kirkby EA(2001) Principles of plant nutrition. 5th edn. Kluwer Academic Publishers, Dordrecht, The Nederlands.

Morrison RS, Brooks RD, Reeves RD, Malaise F, Horowitz P, Aronson M, Merriam GR (1981) The diverse chemical forms of heavy metals in tissue extracts of some metallophytes from Shaba province, Zaire. Phytochemistry 20:455-458.

Murphy A, Zhou J, Goldsbrough PB, Taiz L (1997) Purification and immunological identification of metallothioneins 1 and 2 from Arabidopsis thaliana. Plant Physiol. 113: 1293-1301.

Okamoto OK, Pinto E, Latorre LR, Bechara EJ, Colepicolo P (2001) Antioxidant modulation in response to metal-induced oxidative stress in algal chloroplasts. Arch. Environ. Contam. Toxicol. 40:18-24.

Polle A, Schützendübel A (2003) Heavy metal signalling in plants: Linking cellular and organismic reesponses. In: Hirt H, Shinozaki K. (eds), Plant Stress Response. pp.129. Springer-Verlag, Berlin Heidelberg, Germany.

Radotić K, Dučić T, Mutavdžić D (2000) Changes in peroxidase activity and isoenzymes in spruce needles after exposure to different concentrations of cadmium. Environ. Exp. Bot. 44:105-113.

Rae TD, Schmidt PJ, Pufahl RA, Culotta VC, O'Halloran TV (1999) Undetectable intracellular free copper: the requirement of a copper chaperone for superoxide dismutase. Science 284:805-808.

Ramsay LM, Gadd GM (1997) Mutants of Saccharomyces cerevisiae defective in vacuolar function confirm a role for 
the vacuole in toxic metal ion detoxification. FEMS Microbiol. Lett. 152:293-298.

Rauser WE (1999) Structure and function of metal chelators produced by plants: the case for organic acids, amino acids, phytin, and metallothioneins. Cell Biochem. Biophys. 31:19-48.

Rengel Z (1988) Manganese and its role in biological processes. In: Sigel A, Sigel H (eds), Metal Ions in Biological Systems, pp.69-72. Marcel Dekker, NewYork, USA.

Reuter DJ, Alston AM, McFarlane JD (1988) Occurrence and correction of manganese deficiency in plants. In: Graham RD, Hannam RJ, Uren NC (eds), Manganese in soils and plants, pp.205-224. Kluwer Academic Publishers, Dordrecht, The Nederlands.

Robinson NJ, Wilson JR, Turner JS (1996) Expression of the type 2 metallothionein-like gene MT2 from Arabidopsis thaliana in $\mathrm{Zn}^{2+}$-metallothionein-deficient Synechococcus PCC7942: putative role for MT2 in $\mathrm{Zn}^{2+}$ metabolism. Plant Mol. Biol. 30:1169-1179.

Rodriguez FI, Esch JJ, Hall AE, Binder BM, Schaller GE, Bleecker AB (1999) A copper cofactor for the ethylene receptor ETR1 from Arabidopsis. Science, 283:996-998.

Rogers EE, Eide DJ, Guerinot ML (2000) Altered selectivity in an Arabidopsis metal transporter. Proc. Natl. Acad. Sci. USA 97:12356-1260.

Rudolph HK, Antebi A, Fink GR, Buckley CM, Dorman TE, LeVitre J, Davidow LS, Mao JI, Moir DT (1989) The yeast secretory pathway is perturbed by mutations in $P M R 1$, a member of a $\mathrm{Ca}^{2+}$ ATPase family. Cell 58:133-145.

Sagner S, Kneer R, Wanner G, Cosson JP, Deus-Neumann B, Zenk MH (1998) Hyperaccumulation, complexation and distribution of nickel in Sebertia acuminata. Phytochemistry 47:339-347.

Salt DE, Smith RD, Raskin I (1998) Phytoremediation. Annu. Rev. Plant Physiol. Plant Mol. Biol. 49:643-668.

Sandmann G, Boger P (1980) Copper-mediated lipid peroxidation processes in photosynthetic membranes. Plant Physiol. 66:797-800.

Schmidke I, Stephan UW (1995) Transport of metal micronutrients in the phloem of castor bean (Ricinus communis) seedlings. Physiol. Plant. 95:147-153.

Schmidt U 2003 Enhancing phytoextraction: the effect of chemical soil manipulation on mobility, plant accumulation, and leaching of heavy metals. J. Environ. Qual. 32: 1939-1954.

Schmöger ME, Oven M, Grill E (2000) Detoxification of arsenic by phytochelatins in plants. Plant Physiol. 122:793-801.

Schützendübel A, Polle A (2002) Plant responses to abiotic stresses: heavy metal-induced oxidative stress and protection by mycorrhization. J. Exp. Bot. 53:1351-1365.

Schützendübel A, Schwanz P, Teichmann T, Gross K, Langenfeld-Heyser R, Godbold DL, Polle A (2001) Cadmium-induced changes in antioxidative systems, hydrogen peroxide content, and differentiation in Scots pine roots. Plant Physiol. 127:887-898.

Shenker M, Fan TWM, Crowley DE (2001) Phytosiderophores influence on cadmium mobilization and uptake by wheat and barley plants. J. Environ. Qual. 30:2091-2098.

Shenker M, Plessner OE, Tel-Or E (2004) Manganese nutrition effects on tomato growth, chlorophyll concentration, and superoxide dismutase activity. J. Plant Physiol. 161 (2):197-202.

Shigaki T, Pittman JK, Hirschi KD (2003) Manganese specificity determinants in the Arabidopsis metal $/ \mathrm{H}^{+}$antiporter CAX2. J. Biol. Chem. 278:6610-6617.

Stadtman ER, Berlett BS, Chock PB (1990) Manganese-dependent disproportionation of hydrogen peroxide in bicarbonate buffer. Proc. Natl. Acad. Sci. USA 87:384-388.

Tanaka K, Takio S, Satoh T (1995) Inactivation of the cystolic $\mathrm{Cu} / \mathrm{Zn}$ superoxide dismutase induced by copper deficiency in suspension cultured cells of Marchantia paleacer var. diptera. J. Plant Physiol. 146:361-365.

Tester M, Leigh RA (2001) Partitioning of nutrient transport processes in roots. J. Exp. Bot. 52:445-457.

Van Assche F, Clijsters H (1990) Effect of metals on enzyme activity in plants. Plant Cell Environ. 3:195-206.

Vassilev A, Schwitzguebel JP, Thewys T, Van Der Lelie D, Vangronsveld J (2004) The use of plants for remediation of metal-contaminated soils. Scient. World J. 4:9-34.

Vatamaniuk OK, Mari S, Lu YP, Rea PA (1999) AtPCS1, a phytochelatin synthase from Arabidopsis: isolation and in vitro reconstitution. Proc. Natl. Acad. Sci. USA 96:7110-7115.

Vögeli-Lange R, Wagner GJ (1990) Subcellular localization of cadmium and cadmium-binding peptides in tobacco leaves. Plant Physiol. 92:1086-1093.

Wagner GJ (1994) Accumulation of cadmium in crop plants and its consequences to human health. Adv. Agron. 51:173-212.

Wang J, Evangelou BP, Nielsen MT (1992) Surface chemical properties of purified root cell walls from two tobacco genotypes exhibiting different tolerance to Mn toxicity. Plant Physiol. 100:496-501.

West AH, Clark DJ, Martin J, Neupert W, Hart FU, Horwich AL (1992) The Saccharomyces cerevisiae High Affinity Phosphate Transporter Encoded by PHO84 Also Functions in Manganese Homeostasis. J. Biol. Chem. 267: 24625-24633.

Yamaguchi K, Suzuki I, Yamamoto H, Lyukevich A, Bodrova I, Los DA, Piven I, Zinchenko V, Kanehisa M, Murata $\mathrm{N}$ (2002) Two-component $\mathrm{Mn}^{2+}$-sensing system negatively regulates expression of the mntCAB operon in Synechocystis. Plant Cell 14:2901-3013.

Yu Q, Osborne LD, Rengel Z (1998) Micronutrient deficiency influences plant growth and activities of superoxide dismutase and ascorbate peroxidase in tobacco plants. J. Plant Nutr. 21:1427-1437.

Yu Q, Rengel Z (1999) Micronutrient deficiency influences plant growth and activities of superoxide dismutase and ascorbate peroxidase in narrow leaf lupines. Ann. Bot. 183:175-182.

Yu W, Santhanagopalan V, Sewell AK, Jensen LT, Winge DR (1994) Dominance of metallothionein in metal ion buffering in yeast capable of synthesis of (gamma EC)nG isopeptides. J. Biol. Chem. 269:21010-21015.

Zhongyi W, Feng L Bimei H, Jeff C, Y Michael RS, Jeffrey FH, Heven S (2002) An endoplasmic reticulum-bound $\mathrm{Ca}^{2+}$ / $\mathrm{Mn}^{2+}$ pump, ECA1, supports plant growth and confers tolerance to $\mathrm{Mn}^{2+}$ stress. Plant Physiol. 130:128-137.

Zhou J, Goldsbrough PB (1994) Functional homologs of fungal metallothionein genes from Arabidopsis. Plant Cell 6:875-884. 